\title{
Ficha Limpa - uma lei a defender?
}

\section{CHICO WHITAKER ${ }^{I}$}

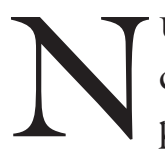

UMA democracia é sempre possível fazer mudanças nas leis e normas com que funcionam as instituições políticas e a economia de um país, a partir dos problemas e possibilidades que vão surgindo. Essas mudanças se tornam às vezes muito necessárias para tornar a vida do país mais democrática.

Elas podem ser propostas passo a passo, assim como podem compor um conjunto mais amplo de leis e regras novas, a que se dá o nome de "reforma política", que pode incluir alterações até na Constituição do país. O processo político que estávamos vivendo até agora nos levava a afirmar a urgência de uma tal reforma, ante os impasses que se apresentavam.

Mas nossa democracia abriu espaço para uma retomada do poder político pela minoria privilegiada do país - ela sempre manteve o poder econômico. E como ocorre com todo regime autoritário ou governo ilegítimo que consegue assumir o poder, os atuais detentores do poder político estão impondo com pressa, aproveitando-se rapidamente das maiorias parlamentares e eleitorais com que agora contam, mudanças que consolidem o poder reconquistado e recuperem os privilégios dos setores sociais que representam. E já começam também a afirmar a necessidade de uma "reforma política", numa direção, no entanto, diferente da que prevalecia antes.

Caberia, portanto, nos interrogarmos se estaria em risco uma lei como a da Ficha Limpa, que se situou na perspectiva de reformas passo a passo, visando elevar o nível ético dos eleitos ao Legislativo e ao Executivo. A "reforma política" proposta pelo poder instalado poderá alterá-la, diminuindo os efeitos que buscávamos? Tudo dependerá da capacidade de resistência dos que se mobilizaram para que essa Lei fosse apresentada ao Congresso e aprovada.

É certo que constitui um mau augúrio a primeira investida ocorrida contra ela, desqualificando de maneira desrespeitosa seus autores - que veio nada mais nada menos do que de um membro do Supremo Tribunal Federal, a mais alta Corte do Poder Judiciário do país. ${ }^{1}$ E que foi acompanhada de uma decisão dessa Corte limitando os efeitos de um dos incisos da Lei, referido a decisões dos Tribunais de Contas.

Esse "movimento de peças" do xadrez político provocou naturalmente um protesto do Movimento de Combate à Corrupção Eleitoral, que propôs aos cidadãos e cidadãs brasileiros a Iniciativa Popular de Lei de que resultou a Lei da Ficha Limpa. E um artigo, refutando os argumentos do ministro quanto à 
insegurança jurídica que ele dizia ter sido criada por essa Lei, foi logo publicado por um grande jornal, com um título sugestivo: "Ficha Limpa, a ficha que não pode cair". ${ }^{2}$

Segundo o STF a Lei em questão teria dado aos Tribunais de Contas um poder que não deveria, em sua opinião, lhes caber, ao tornar inelegíveis os prefeitos cujas contas de gestão não tivessem sido aprovadas por esses Tribunais. Considerando o conteúdo dessa decisão, o artigo que a refutou foi escrito pelo juiz Marlon Reis, cofundador do MCCE e um dos principais redatores do projeto de Lei, juntamente com Valdecir Pascoal, presidente da Associação dos Membros dos Tribunais de Contas (Atricon) e Conselheiro do Tribunal de Contas do Estado de Pernambuco - um dos especialistas que contribuíram, com conhecimento de causa, para a redação final do inciso da Lei assim questionado.

Os autores do artigo, deixando elegantemente de mencionar o modo pouco feliz com que o ministro havia se referido a eles e aos outros autores da Lei, criticaram a decisão do STF, que infelizmente indicava um imperdoável desconhecimento do assunto. Eles disseram que essa decisão, que transferiu "dos Tribunais de Contas às Câmaras de Vereadores a competência para julgar as contas de gestão de prefeitos é um passo atrás em nossa accountability, pois compromete, em grande medida, a efetividade do controle e o propósito fundamental da Lei da Ficha Limpa, que é o de melhorar a qualidade da gestão e da democracia".

E lembraram que "contas de gestão", referidas na Lei da Ficha Limpa, não são o mesmo que "contas de governo", relativas ao cumprimento do orçamento municipal como um todo. Essas só podem de fato - como determina a Constituição - ser aprovadas ou rejeitadas por decisão, sempre política, das Câmaras de Vereadores. Mas as "contas de gestão" são apresentadas aos Tribunais de Contas pelos "operadores de despesas" e são por eles analisadas tecnicamente. Essa função de "operadores de despesas" ("assinar empenhos, homologar licitações, firmar contratos e determinar pagamentos, etc.") não pode ser assumida pelos prefeitos, e quando esses o fazem - só o conseguem em municípios pequenos - os resultados podem ser desastrosos quanto ao uso de recursos públicos. Por isso mesmo os autores do artigo concluem, não sem uma certa tristeza, que se essa decisão do STF prevalecer "mais de cinco mil prefeitos e ex-prefeitos no país, que tiveram suas contas de gestão rejeitadas pelos Tribunais nos últimos oito anos, ficarão imunes ao benfazejo filtro da inelegibilidade da Lei da Ficha Limpa".

A Lei da Ficha Limpa não é, portanto, algo que possa ser analisada em "conversas de vestiário", para usar a expressão com que se defendeu um dos candidatos à presidência dos Estados Unidos de uma acusação de desrespeito às mulheres. A história e a motivação dessa Lei - indicadas a seguir ${ }^{3}$ - fazem que mereça o maior respeito. 


\section{As origens da Lei de Ficha Limpa}

A Lei da Ficha Limpa se inscreve numa longa caminhada de cidadania no Brasil. Ela resultou de uma inovação da nossa Constituição de 1988, nela introduzida pela participação popular na sua elaboração: os cidadãos e cidadãs passaram a poder submeter Projetos de Lei diretamente ao Legislativo, desde que subscritos por pelo menos $1 \%$ do eleitorado, distribuído em pelo menos cinco estados. A Iniciativa Popular de Lei deu assim, juntamente com o Referendo e o Plebiscito, igualmente previstos na Constituição, um pequeno toque de democracia semidireta ao nosso sistema de governo, ao se estabelecer que todo o poder emana do povo e será por ele exercido por representantes eleitos e por meio desses instrumentos. Foi essa afirmativa que, juntamente com a intensa pressão social que acompanhou a elaboração e aprovação da nova Constituição, levou a que fosse chamada de Constituição Cidadã.

O primeiro passo para conquistar o direito de propor leis foi obra de uma longa mobilização nacional que nasceu paralelamente àquela que exigia uma "Constituinte já", ao final do regime militar iniciado em 1964. Conseguiu-se introduzir um artigo no Regimento Interno da Constituinte criando a possibilidade de Emendas Populares ao projeto de Constituição, desde que subscritas por pelo menos 30 mil eleitores. Ao final do prazo para isso estabelecido chegaram ao Congresso 122 Emendas, subscritas por 12 milhões de cidadãos e cidadãs. ${ }^{4}$ Duas delas propunham os três instrumentos, e receberam mais de 400 mil assinaturas.

Conquistado o instrumento por uma Emenda Popular, voltou à sociedade a responsabilidade de usá-lo. A primeira Iniciativa Popular de Lei só foi, no entanto, aprovada pelo Congresso em 1994. Ela tipificava os crimes hediondos, e foi proposta depois do assassinato, que comovera a nação, de uma atriz filha de uma escritora de telenovelas. ${ }^{5}$ Mas logo depois de ser lançada a coleta de assinaturas o Executivo encampou a Iniciativa e conseguiu sua rápida aprovação. $\mathrm{O}$ Projeto de Lei que primeiro obedeceu de fato às exigências para as Iniciativas Populares tinha sido levado ao Congresso dois anos antes, em 1992, com as 700 mil assinaturas então necessárias, colhidas por movimentos de moradia propondo a criação de um Fundo Nacional de Habitação. Mas só se conseguiu aprová-lo - com evidentemente muitas modificações - 17 anos depois ${ }^{6} \ldots$

O segundo e o terceiro Projetos levados ao Congresso - o que visava impedir a compra de votos de eleitores e o da Ficha Limpa - tiveram mais sorte. O texto original de ambos foi também devidamente modificado, como é normal que ocorra com todo projeto de lei submetido a uma assembleia de representantes de diferentes interesses. Mas o relativo à compra de votos foi protocolado em agosto de 1999, com um milhão de assinaturas (correspondendo ao $1 \%$ do eleitorado naquele momento), e foi aprovado e sancionado no tempo recorde de 42 dias. ${ }^{7}$ Enquanto o terceiro - o da Ficha Limpa - que chegou ao Congresso com o milhão e trezentas mil assinaturas então necessárias foi aprovado somente oito meses depois. ${ }^{8}$ 


\section{O elevado número de assinaturas exigidas - primeiro obstáculo à proposição da Lei da ficha Limpa}

O primeiro obstáculo encontrado pelos propositores da Lei da Ficha Limpa foi a que se apresenta para a Lei de Iniciativa Popular em geral: esse número elevado de assinaturas necessárias, fixado na Constituição. Ele traduz possivelmente uma preocupação em limitar a força que pode ganhar a participação popular, depois de constatado que o limite estabelecido para as Emendas Populares à Constituição (30 mil assinaturas) foi largamente superado pela resposta da sociedade (12 milhões em 122 Emendas). Mas constitui de fato um primeiro e grande obstáculo à utilização desse instrumento: a Iniciativa relativa à compra de votos exigiu um ano e meio de coleta de assinaturas. E seus propositores só não desistiram, depois de conseguidas as primeiras 500 mil, porque acontecimentos ligados a grandes meios de comunicação criaram a consciência do interesse em impedir a compra de votos na eleição de vereadores e outros parlamentares. ${ }^{9}$

O mesmo ocorreu com a coleta de assinaturas para o Projeto de Lei da Ficha Limpa: levou-se também um ano e meio para se alcançar o número mínimo então necessário. E dessa vez foi o tipo mesmo de demanda que ele continha - e que já respondia a um sentimento generalizado de descontentamento com a qualidade ética dos chamados "políticos" - que acabou por mobilizar amplamente a sociedade para que fosse aprovado.

O elevado número de assinaturas exigidas sem dúvida reduziu muito o número de Iniciativas até agora apresentadas. A terceira, da Ficha Limpa, foi levada ao Congresso dia 29 de setembro de 2009, exatos dez anos depois da promulgação da Lei contra a compra de votos, e 20 anos depois do instrumento ter sido criado. Só mais recentemente, com a divulgação que ele ganhou com a Ficha Limpa, começaram a se multiplicar as propostas de Iniciativa Popular.

Uma dessas propostas é a do movimento Greenpeace, com um projeto de lei chamado de "Desmatamento Zero", contra a destruição de nossas florestas, entregue ao Congresso em outubro de 2015, isto é, cinco anos depois da aprovação da Lei da Ficha Limpa. Lançado em março de 2012, esse projeto conseguiu chegar a 1,4 milhão de assinaturas três anos e meio depois - embora se tenham sido utilizadas complementarmente, para divulgá-las mais, adesões por via eletrônica. A mais recente, com medidas contra a corrupção, ${ }^{10}$ foi levada ao Congresso um ano depois. Lançada a coleta em 27 de julho de 2015, em 29 de março de 2016 ela tinha conseguido dois milhões de assinaturas e foi entregue ao Congresso. Mas essa maior rapidez na coleta só foi possível por ter sido proposta por procuradores do Ministério Público Federal que utilizaram, para obter assinaturas, a própria estrutura e a imagem de seu prestigioso organismo de Estado, em um momento em que a corrupção se tornou um dos principais focos da luta política.

Nas demais Iniciativas, os movimentos que as propuseram continuam no vagaroso afã de recolher e contar assinaturas, o que só não desanima cidadãos e cidadãs profundamente interessados no objetivo do projeto pelo qual se mobilizam. 
Por essa razão houve várias tentativas de reduzir o mínimo de assinaturas exigidas, por iniciativa de parlamentares partidários da participação popular. É significativo constatar que a última delas - um Projeto de Emenda Constitucional (PEC) aprovado pelo Senado em 10 de julho de 2013 - foi proposto logo depois das manifestações de rua de junho de 2013 e procurava responder a elas, dentro do que foi chamado de "agenda positiva" do Congresso, urgentemente necessária diante de uma mobilização social que surpreendeu o mundo político. Essa PEC diminui o mínimo para $0,5 \%$ do eleitorado, abre a possibilidade de Iniciativas Populares de Emenda à Constituição e de emendas a projetos de lei em tramitação (com um mínimo de $1 \%$ de assinaturas), cria a possibilidade de assinaturas por meio eletrônico e a possibilidade, a pedido de um partido, de o projeto ganhar prioridade de tramitação no Congresso. Mas o fato de não ter sido até hoje submetida à Câmara mostra que pode corresponder somente a um episódio de oportunismo político.

\section{O obstáculo da tramitação no Congresso}

O segundo obstáculo que a Lei da Ficha Limpa enfrentou, que poderia ter impedido até que tramitasse, foi também enfrentado pelos projetos anteriores e decorreu do fato de ser literalmente impossível autenticar em prazo curto todas as assinaturas (as folhas com essas assinaturas teriam que ser enviadas aos cartórios dos municípios de cada subscritor). A solução encontrada foi a de fazê-las tramitar como iniciativa parlamentar. Subscritas por um parlamentar que seja, elas passam a tramitar imediatamente depois de protocoladas.

Mas nem a Constituição nem Leis Complementares posteriores estabeleceram que, dado o seu caráter, elas deveriam ter uma tramitação especial. Ora, todo parlamentar sabe muito bem que todo projeto que apresente corre o risco de ser mantido indefinidamente na vala comum dos milhares de outros apresentados por seus colegas, além de serem sempre considerados menos urgentes do que os apresentados pelo Executivo. Assim, mesmo em condições, por assim dizer, excepcionais, como a da Iniciativa das "Dez medidas contra a corrupção", os propositores desse Projeto de Lei consideram - apesar de toda a visibilidade que o MPF ganhou por sua ação contra a corrupção - que sua tramitação, incluindo a necessária no Senado, só terminará em meados de 2017.

A experiência da lentidão que se verificou com a primeira Iniciativa Popular, propondo o Fundo de Habitação Popular - subscrita por um único parlamentar e levando 17 anos para ser aprovada - levou os movimentos da sociedade civil que propuseram a segunda e a terceira a obter que fossem subscritas por um número maior e mais representativo de parlamentares. Esse número aumentou bastante no caso da Ficha Limpa, que já respondia a um anseio da sociedade mais forte do que o de impedir a compra de votos, que é um procedimento bastante aceito - até hoje aliás - na cultura política brasileira.

Eles se organizaram melhor também para seguir de mais de perto essa tramitação. Até porque, no caso da compra de votos, era difícil a um parlamentar 
ser contra o Projeto, porque isso corresponderia a declarar que pretendia comprar votos - pretendesse de fato ou não... Mas no caso da Ficha Limpa, dado o grande número de parlamentares que tem dificuldades com a Justiça - ainda que protegidos pelo Foro Privilegiado - muitos parlamentares diziam, quando foi levado à Câmara, que era "mais fácil uma vaca voar do que esse projeto ser aprovado"... Isto explica bem a diferença de tempo de tramitação dos dois Projetos.

De fato, o trabalho intenso e continuado, feito pelos propositores de tão difícil Lei, para que o Projeto não caísse na vala comum, foi plenamente assumido também - algo que pode ser visto como inusitado - por muitos deputados dos mais variados partidos e pelas lideranças partidárias mais decisivas, tendo contado com a colaboração de muitos especialistas de fora do Congresso bem como de deputados conhecedores dos temas nele considerados, e contou além disso com a boa vontade e a ajuda da própria Presidência da Câmara. ${ }^{11}$ Esses fatos dão ainda menos consistência ao modo como o ministro do STF se referiu aos seus autores, citado no início deste texto. ${ }^{12}$

Essa insuficiência no tratamento da questão levou também parlamentares envolvidos no desenvolvimento da participação popular a proporem outros instrumentos que the dessem a importância que merecem. Tal foi o caso de criação da Comissão de Participação Legislativa, em 2001, que recebe Projetos de Lei até de pessoas isoladas, e garantem uma tramitação especial àqueles que forem assumidos pela Comissão. ${ }^{13}$ Os propositores da Iniciativa Popular do "Desmatamento Zero", acima referida, preferiram por isso dar entrada de seu Projeto nessa Comissão e não junto à Mesa da Câmara.

\section{A potencialidade pedagógica da Lei da Ficha Limpa}

A dificuldade em coletar um número tão elevado de assinaturas foi na prática transformado em ganho, numa perspectiva democrática. O sem número de apresentações, debates, campanhas que se fazem, ao longo de muito tempo, para convencer os eleitores a assinarem a Iniciativa, termina por esclarecer e interessar um número crescente de pessoas nos objetivos do Projeto de Lei. E isso se faz com maior facilidade - embora em tempo sempre longo - se ele responde a um anseio da sociedade, como foi o caso da Lei da Ficha Limpa, criando alguma esperança de que o problema que enfrenta seja superado.

Essa é, aliás, uma importante dimensão pedagógica desse instrumento, numa perspectiva de educação política dos cidadãos, por meio da difusão de frases na divulgação das campanhas de assinaturas. A usada na Lei contra a compra de votos - "voto não tem preço, tem consequências" - foi uma excelente forma de elevar a consciência da importância do voto numa democracia. E a ideia de que representantes do povo tem que ter uma "Ficha Limpa", para cumprir essa função, penetrou tanto nas consciências que as próprias organizações que compõem o Movimento de Combate à Corrupção Eleitoral, que a levou ao Congresso, decidiram aplicar os mesmos critérios da Lei nas eleições de seus dirigentes. 
Tudo isso leva pouco a pouco os que promovem a coleta de assinaturas e os subscritores do Projeto de Lei a considerarem que essa Lei lhes pertence, passando a ver a sua aprovação como sua conquista. Isso se demonstrou pela própria ajuda recebida - especialmente no caso da Lei contra a compra de votos - pelos membros das organizações propositoras que seguiam sua tramitação, por parte de funcionários do Congresso - que certamente estavam entre os cidadãos e cidadãs que subscreveram o projeto. Isso dá às Leis de Iniciativa Popular um peso político peculiar.

\section{A participação e a articulação política estimuladas pela Lei da Ficha Limpa}

O peso político das Iniciativas Populares de Lei é uma decorrência também do engajamento das organizações da sociedade civil que as apresentam e recolhem assinaturas. No caso da primeira bem-sucedida, contra a compra de votos, a Conferência Nacional dos Bispos do Brasil (CNBB) aprovou por grande maioria, em Assembleia Geral, a proposta que lhe foi apresentada por alguns organismos de Igreja ${ }^{14}$ e movimentos sociais. E o Projeto recebeu logo em seguida o apoio do Conselho Federal da Ordem dos Advogados do Brasil (OAB). No caso da Lei de Ficha Limpa, o apoio da CNBB foi pedido dez anos depois pelo Movimento de Combate à Corrupção Eleitoral, criado pelos movimentos sociais que tinham se empenhado na coleta de assinaturas da primeira Iniciativa Popular. E esse apoio foi dado por decisão unânime de sua Assembleia Geral, seguido também do apoio da OAB.

O engajamento da CNBB foi, por outro lado, decisivo na coleta de assinaturas, pela capilaridade da presença da Igreja Católica em todo o país. Mas seguramente também influenciou a decisão do Congresso - no caso da lei contra a compra de votos, ela era nele conhecida como a "lei dos bispos" - pela necessidade dos parlamentares gozarem, para fins eleitorais, da simpatia dos prelados.

Para completar esse quadro, é preciso indicar que à medida que o Projeto foi tramitando, ele ganhou um apoio crescente da grande mídia, que passou também a pressionar os parlamentares para sua aprovação.

A articulação política fica evidente se considerarmos que o Movimento de Combate à Corrupção Eleitoral (MCCE), que preparou e apresentou o Projeto de Lei da Ficha Limpa - criado em 2002 a partir dos "Comitês 9840", em que se organizaram os cidadãos e cidadãs para fiscalizar o cumprimento da Lei n.9840/99 contra a compra de votos - reúne em rede, hoje, mais de 60 entidades da sociedade civil, e conta com Comitês Estaduais em quase todos os estados brasileiros e em muitos municípios. E foi esse Movimento que decidiu relembrar, em recente reunião plenária em Brasília, como uma forma de responder ao ataque que a Lei da Ficha Limpa tinha então sofrido no STF, a orientação que adotara quando da proposição do Projeto, como indicado acima: respeitar os critérios dessa Lei também na aceitação de candidaturas aos cargos de direção dos movimentos e entidades que o compõem. 


\section{A Presunção de Inocência e o Direito de Precaução}

É fundamental, no entanto, numa apresentação da Lei da Ficha Limpa e do seu peso político na atual etapa da democracia brasileira, indicar seu conteúdo inovador, especialmente quanto à proposta em torno da qual foi maior a dificuldade para sua aprovação no Congresso: a mais consistente e diversificada resistência ao que propunha foi devida a que ele desrespeitava - segundo seus opositores tanto de direita como de esquerda - o princípio da Presunção de Inocência, fundamental em toda democracia.

Esse princípio é, sem dúvida, uma das grandes conquistas da Humanidade, a garantia do cidadão contra os abusos do poder: ninguém pode ser considerado culpado antes de esgotadas todas as possibilidades de recursos, ou, como se formula na linguagem jurídica, antes do trânsito em julgado da sentença. Assim, a acusação de que o Projeto de Lei da Ficha Limpa desrespeitava esse princípio levantou contra ele muitos eminentes juristas, bem como respeitáveis líderes políticos. A percepção de que era muito difícil aprová-lo vinha, sem dúvida, primeiramente do fato de que grande número de parlamentares estava sendo processado por crimes às vezes muito graves. Mas a resistência que iriam opor se somaria àquela dos que defendiam o princípio da Presunção de inocência como um direito individual inalienável.

Os propositores da Lei argumentavam, em contrário, que não se tratava de desrespeitar esse princípio, mas de respeitar outro direito, de interesse coletivo, que é o Direito de Precaução: a sociedade tem o direito de se proteger preventivamente da ação, no Parlamento ou no Executivo, de pessoas que pudessem ser eleitas como representantes dos seus concidadãos, mas tivessem uma vida pregressa questionada na Justiça e, portanto, duvidosa. Ou, em outras palavras, as pessoas com uma "Ficha Suja" - como se dizia quando se discutia a Lei - continuariam resguardadas de serem consideradas culpadas até trânsito em julgado dos processos a que estivessem respondendo, mas a sociedade tomava a precaução de defender-se, preventivamente, de ações prejudiciais à coletividade que seu passado tornaria possíveis.

Considerava-se, por outro lado, que a eleição desses candidatos thes daria um Foro Privilegiado que poderia tornar ainda mais demorados seus julgamentos pelo Poder Judiciário - com a lentidão que o caracteriza. E que a obtenção de mandatos eletivos era uma estratégia conhecida para aumentar ainda mais as possibilidades de múltiplos recursos, abertas pelo nosso Código de Processo Penal, para que as pessoas se defendam em infindáveis processos, até a prescrição de seus delitos.

Foi assim em torno dessa questão que se travou a maior batalha para a aprovação da Lei de Ficha Limpa, que se prolongou mesmo depois de aprovada, pelos recursos interpostos junto ao Tribunal Superior Eleitoral e ao Supremo Tribunal Federal.

Mas uma tal controvérsia já tinha disso levantada em torno da Iniciativa Popular contra a compra de votos ${ }^{15}$ aprovada dez anos antes. Na discussão 
dessa questão tinha se empenhado o próprio presidente do Tribunal Superior Eleitoral na ocasião, ${ }^{16}$ ao constatar que a suspeita de inconstitucionalidade dessa Lei, com base no princípio universal da Presunção de Inocência, começava a ser levantada por Tribunais Regionais Eleitorais. ${ }^{17}$ Ele realizou então um verdadeiro périplo de encontros com os TRE de todo o país, para convencê-los de que a Lei n.9.840/99 era mais do que bem-vinda pelo TSE, ao permitir que a Justiça Eleitoral ganhasse maior eficácia no aprimoramento dos processos eleitorais. Ela de fato podia finalmente enfrentar, segundo ele de maneira correta juridicamente, a conhecida capacidade dos advogados de postergar indefinidamente sentenças que no caso tornariam seus clientes inelegíveis.

Seus argumentos eram do mesmo tipo do expressado pelo ministro então titular da Controladoria Geral da União, em artigo publicado pela Folha de S.Paulo, ${ }^{18}$ que mostrava a quantidade de recursos que podem ser interpostos, no Brasil, para postergar essa "decisão final". Ele diz, nesse artigo, depois de reafirmar que todo país civilizado respeita os princípios da "ampla defesa" e da "presunção de inocência" como cláusulas fundamentais de garantia do cidadão, nenhum deles extrai o que se faz no Brasil. Aqui, esperar o trânsito em julgado

$[\ldots]$ quer dizer que $[\ldots]$ se tem de esperar a interposição e o julgamento, pelo menos, dos seguintes recursos: um ou vários recursos em sentido estrito e um ou vários embargos declaratórios no primeiro grau; uma apelação após a sentença; um ou vários embargos declaratórios e um embargo infringente no tribunal de segundo grau; se houver alguma decisão do relator, mais alguns declaratórios e um agravo regimental; depois, vêm o recurso especial (para o Superior Tribunal de Justiça) e o extraordinário (para o STF); se inadmitidos estes pelo Tribunal de Justiça (ou Tribunal Regional Federal), vem o agravo de instrumento para forçar a admissão, o qual será examinado pelo relator, de cuja decisão podem caber novos agravos regimentais e embargos declaratórios (que, aliás, cabem de cada uma das decisões antes mencionadas, e repetidas vezes da mesma, bastando que se diga que restou alguma dúvida ou omissão). [...] nem falamos ainda nas dezenas de outros incidentes processuais que os bons advogados sabem suscitar, dentro ou fora das previsões legais expressas, além dos habeas corpus e mandados de segurança, em quaisquer das instâncias. [...] $\mathrm{O}$ autor conclui: “...até as pedras sabem que isso vai demorar pelos menos uns 15 ou 20 anos" [...]

Os autores do projeto de lei contra a compra de votos ${ }^{19}$ tinham encontrado de fato uma forma inteligente de impedir que potenciais criminosos se apresentassem como candidatos. Segundo o projeto, seus processos poderiam evidentemente continuar a correr, mas por decisão administrativa o Juiz Eleitoral de sua Comarca poderia negar o registro de sua candidatura se tivesse sido julgado culpado de crime em pelo menos uma instância colegiada do Poder Judiciário.

Ora, a Lei da Ficha Limpa dava um passo a mais, impedindo esse registro quando o candidato tivesse sido julgado culpado - sempre por um colégio de juízes - por uma série específica de crimes, indicados em 21 incisos. 
O MCCE divulgara, no início do processo de sua discussão, uma nota de resposta a uma conceituada publicação do meio jurídico ${ }^{20}$ que atacara o Projeto no tocante à Presunção de Inocência. Nessa nota ele dizia:

$[\ldots]$ cresce um consenso em torno da impossibilidade de impor esse princípio do Direito Penal a todas as demais áreas do Direito, como se o país não pudesse tomar precauções para proteger, através do Direito Eleitoral, a moralidade administrativa e a probidade para o exercício de mandatos.

E bem mais adiante um Manifesto, assinado por grande número de juristas conceituados, organizado pelos propositores do Projeto, enfrentou diretamente a questão dizendo, entre outras coisas:

Diz-se que o princípio da presunção de inocência, também sediado na Constituição, estaria a impedir que condenações não transitadas em julgado viessem a infirmar a elegibilidade de alguém. Essa alegação é destituída de fundamentação jurídica, pois se volta apenas a impedir a aplicação imediata das sanções de natureza penal. E inelegibilidade não é pena, mas medida preventiva.

[...] Afirmar-se que o princípio da presunção de inocência se estende a todo o ordenamento jurídico constitui evidente impropriedade. Estender-se-ia ao Direito do Trabalho, para impedir a demissão de um empregado ao qual se atribui crime de furto até que transite em julgado a sua condenação criminal? Serviria ele para impedir que uma creche recuse emprego a alguém que já foi condenado por crimes sexuais contra crianças?

[...] Diante de tais razões, os juristas abaixo-assinados afirmam que o princípio da presunção de inocência não se aplica ao tema das inelegibilidades.

A resistência ao conteúdo do Projeto vinha também por outras razões, apresentadas por parlamentares e por partidos. Esses consideravam que a Lei iria judicializar indevidamente a atividade política, e temiam que a nova norma pudesse ser usada na luta política, impedindo suas lideranças de se candidatarem - um temor que era expressado também por movimentos sociais. $\mathrm{O}$ mesmo tipo de resistência já tinha surgido quando da aprovação da Lei n.9.840, contra a compra de votos, pela possibilidade de serem montadas pretensas compras de votos que levariam à impossibilidade de registrar candidaturas contrárias ao poder dominante em cada lugar. Essa possibilidade, quanto a essa Lei, só pode ser verificada por ocasião da primeira eleição em que passou a ter vigência, e criou de fato situações de provável injustiça, de difícil solução na medida em que as Leis têm que valer para todos.

\section{As múltiplas etapas da tramitação}

A discussão do Projeto de Lei da Ficha Limpa passou por múltiplas etapas dentro da Câmara e depois no Senado, cada vez mais acompanhadas de perto pela imprensa - que frequentemente levantava a hipótese de estar sendo desfigurado ou simplesmente engavetado.

Logo de início foi criada uma Comissão Especial para analisá-lo, não prevista no Regimento Interno. ${ }^{21}$ Ela foi constituída, como sempre, por deputados de todos os partidos, para considerar todos os projetos de lei já em tramitação a 
respeito da mesma questão - dos quais o primeiro era de 1993. Suas propostas foram então incorporadas ao projeto apresentado pelos propositores da Lei da Ficha Limpa, quando pertinentes e quando aperfeiçoavam seu conteúdo, e sua redação tornada mais precisa.

Ele foi em seguida discutido na Comissão de Constituição e Justiça (CCJ), com o compromisso dos líderes partidários dos dois maiores partidos de levá-lo ao Plenário da Câmara, com ou sem parecer dessa Comissão, no prazo de 30 dias. Finalizado esse prazo, ele foi submetido ao Plenário sem o parecer da CCJ, com "urgência urgentíssima", como tinha sido acordado pelas lideranças da Casa e sua presidência. E depois de muitos destaques apresentados e rejeitados pela maioria, o Projeto foi aprovado - com mais votos do que o exigido para uma Lei Complementar, como era o caso dessa Lei - e enviado ao Senado.

No Senado, uma nova celeuma se criou, com uma emenda aprovada considerada de redação para que o projeto não voltasse para a Câmara - que levantou dúvidas quanto à intepretação da frase "se for condenado", que substituiu num dos primeiros artigos da Lei a frase "políticos que tenham sido condenados", o que criou a possibilidade da sua aplicação se ater somente aos crimes e julgamentos ocorridos depois de sua promulgação.

Mas um dos juristas que a apoiavam forneceu argumentos para esclarecer a questão, ${ }^{22} \mathrm{em}$ artigo em que dizia:

"Os que forem brasileiros me sigam". Essa exortação ao heroísmo, atribuída ao Duque de Caxias, evidentemente não se referia àqueles que, no futuro, se tornassem brasileiros, mas era dirigida aos que naquele momento tivessem a condição de brasileiros autênticos e que deveriam agir como tais.

[...] Mais tarde, quando se introduziu o divórcio no sistema jurídico brasileiro, a lei $n^{\circ} 6515$, de 26 de dezembro de 1977, dispôs que poderia ser dada a separação judicial dos cônjuges "se forem casados há mais de dois anos".

[...] As expressões "forem casados" e "forem brasileiros" designavam, precisamente, uma condição ou qualidade, nada tendo a ver com acontecimentos futuros.

[...] Ninguém poderá, honesta e sinceramente, duvidar do objetivo da lei, que é impedir a candidatura dos que tiverem sido judicialmente reconhecidos como corruptos e por isso inaptos para representar qualquer segmento da cidadania brasileira.

\section{A "novela" da Ficha Limpa}

Mas depois que a "vaca voou", como se disse na Câmara dos Deputados, a discussão do projeto continuou por mais oito meses, no Tribunal Superior Eleitoral e no Supremo Tribunal Federal, por força de recursos e de questionamentos que lhe eram feitos na Justiça.

Nesse período o momento culminante foi o empate no STF de cinco votos a cinco, na decisão sobre sua constitucionalidade. Essa decisão ficou vários meses dependendo da nomeação, pelo presidente da República, de um $11^{\circ}$ ministro, 
em substituição ao que tinha se aposentado. Seu voto de desempate decidiria se aquela Corte consideraria constitucional ou não o projeto.

Nomeado e empossado o novo ministro, esse voto foi dado no dia 23 de março de 2011, a favor da constitucionalidade da Lei. Mas o STF estabeleceu que ela só teria validade nas eleições de 2012, por ter sido promulgada em 4 de junho de 2010, isto é, menos de um ano antes das eleições desse mesmo ano.

Sobre esse período, tomo a liberdade de transcrever trechos de artigo que escrevi com o título "Lula e a novela da Ficha Limpa", publicado na revista Carta Capital em 25 de novembro de 2010. ${ }^{23}$

A história da Lei da Ficha Limpa é um autêntico roteiro de novela de sucesso, com seus suspenses, alegrias e tristezas, surpresas e alívios. [...]

O Senado pregaria no entanto um susto: aprovou uma pequena emenda, que se dizia que não era anódina e tinha endereço certo. Ela obrigaria o projeto a voltar para a Câmara, se fosse considerada de mérito. Mas interpretada como emenda de redação, tudo terminou em paz.

No capítulo seguinte da novela, surgiu um novo e importante ator: o Tribunal Superior Eleitoral. Seu Presidente, recém-empossado, criou um novo suspense levantando de novo a dúvida: seria a nova Lei constitucional ou não? Mas em sucessivos julgamentos de casos concretos o TSE resolveu essa e outras duas questões, com um quórum tranquilo de 5 a 2 que incluiu o voto favorável de seu Presidente: constitucional, sim; compreendendo condenações anteriores à lei, sim; valendo já na eleição de 2010, sim.

O capítulo que estamos vivendo agora decorreu do direito dos condenados pelo TSE a recorrerem ao STF. Seus primeiros episódios foram longos e emocionantes. Em duas sessões seguidas do Supremo, cada Ministro ia justificando longamente sua posição, um após o outro, acompanhados pela TV em todo o Brasil e por manifestações do lado de fora do prédio. No segundo desses julgamentos os telespectadores tiveram direito até a cenas explícitas de partidarização, e muitos ficaram estupefatos com comportamentos que não corresponderiam ao de calmos Magistrados. E com o empate de 5 a 5 , nos dois julgamentos, a continuidade da novela ficou na dependência do surgimento de um personagem ainda desconhecido: o ocupante ou a ocupante da $11^{\text {a }}$ vaga desse Tribunal $[\ldots]$.

Seu último capítulo vai ser filmado na sala majestosa da mais alta Corte do país, onde os "bons" e os "maus", acompanhados pela televisão em todo o Brasil, vão quebrar o empate em que se encontram.

Ao que tudo indica esse capítulo só irá ao ar no ano que vem, para que o suspense seja bem prolongado. E sem que os telespectadores vejam Lula, o personagem que se tornou decisivo nesse fim de novela. Ele ficará detrás das câmeras, depois de designar o Ministro ou Ministra que ocupará a $11^{\text {a }}$ vaga do Supremo. [...]

Chegamos assim ao suspense final: neste capítulo poderá ser jogado por terra todo o imenso e custoso esforço feito pela sociedade brasileira e pelos setores do Congresso Nacional que o honraram. Se o $11^{\circ}$ Ministro ou Ministra entrar no pelotão dos cinco contrários ao projeto, ele sozinho - ou ela sozinha - 
terá mais poder que o próprio Presidente da República, que promulgou a Lei da Ficha Limpa. Com um desempate desfavorável a ela, os prejudicados pelas decisões anteriores do STF pedirão imediatamente a anulação das mesmas. E o sonho de moralização política que essa Lei carrega consigo virará fumaça, ou será empurrado para o imprevisível ano de 2012.

A batata quente, agora nas mãos de Lula, está na verdade fervendo. As sessões do STF mostraram que não é assim tão neutro - ou técnico - nomear um Ministro do Supremo. E o modo como a novela pode terminar já levantou até a hipótese de uma nova proposta para a Reforma Política: a possibilidade de

"impeachment" dos Ministros dessa Corte, se o enorme poder que têm for usado em prejuízo da sociedade.

Como já indicado anteriormente, o ministro nomeado desempatou a favor da constitucionalidade da Lei de Ficha Lima.

\section{"E agora, José?" ${ }^{24}$}

O que temos a reter desses dados é que de fato a Lei da Ficha Limpa não é uma Lei que se possa tratar como outras que passam pelo Congresso sem fazer ruído e muito menos que se possa desrespeitar. Além de sua longa história em que se empenharam desde o mais de um milhão de cidadãos e cidadãs, num trabalho "pessoa a pessoa" de coleta de assinaturas em suas cidades, até um grande número de juristas, deputados e senadores que a elaboraram meticulosamente, com a participação de grandes entidades nacionais como a $\mathrm{CNBB}$ e a $\mathrm{OAB}$, ela é portadora de uma resposta importante às dificuldades que enfrenta desde sempre nosso país: é preciso, urgentemente, elevar o nível ético dos que nos representam nos governos e especialmente nos Legislativos.

Resta saber se teremos a coragem e a disposição necessária para defender a Lei da Ficha Limpa como uma conquista da cidadania brasileira, com a mesma persistência que demonstramos para levá-la a ser aprovada.

17 de outubro de 2016.

\section{Notas}

l O Ministro Gilmar Mendes, do STF, disse, em conversa com jornalistas, que a Lei da Ficha Limpa "parece ter sido feita por bêbados" (@Estadao, versão on-line do jornal O Estado de S. Paulo, 18 de agosto de 2016). Note-se que esse ministro foi um dos cinco membros dessa Corte que votaram pela inconstitucionalidade da Lei em exame, quando se constatou um empate em sua decisão a esse respeito, conforme relatado neste texto.

2 Disponível em: <http://politica.estadao.com.br/blogs/fausto-macedo/a-ficha-que-nao-pode-cair/>.

3 Ver especialmente a nota 11 e todo o parágrafo a que se refere.

4 Ver Cidadão Constituinte - A saga das emendas populares, de vários autores (Paz e Terra 1989). 
5 Lei n.8.930, de 7 de setembro de 1994.

6 Lei n.11.124, de 16 de junho de 2005.

7 Lei n.9.840, de 29 de setembro de 1999.

8 Lei Complementar n.135, de 4 de junho de 2010. O projeto foi entregue ao Congresso com 1,3 milhão de assinaturas de eleitores, mas esse número subiu para 1,7 milhão enquanto ele estava sendo discutido pela Câmara dos Deputados, aos quais se agregaram dois milhões de assinaturas on-line.

9 A denúncia da "máfia dos fiscais" na Câmara Municipal de São Paulo, em que a Rede Globo se empenhou ao ser por ela prejudicada, levantou a questão da relação entre os costumes eleitorais e o comportamento ético dos vereadores.

10 "Dez medidas contra a corrupção".

11 O presidente da Câmara, tanto quando da discussão do Projeto da compra de votos como do Projeto da Ficha Limpa, era o deputado Michel Temer, hoje presidente da República. Seu comportamento como presidente da Câmara, nessas ocasiões, pode nos levar a esperar que não inverta suas posições, se as forças do governo que preside decidirem diminuir o peso político da Lei da Ficha Limpa no ordenamento jurídico do país.

12 Ver nota 1.

13 Comissões semelhantes têm sido criadas em várias Assembleias Legislativas Estaduais e Câmaras de Vereadores.

$14 \mathrm{O}$ principal proponente e animador da Iniciativa foi a Comissão Brasileira Justiça e Paz, organismo de leigos vinculado à CNBB.

15 Ver nota 7.

16 O presidente do TSE nessa ocasião era o ministro do STF Nelson Jobim.

17 O primeiro a se pronunciar nesse sentido foi o TRE de Santa Catarina.

$18 \mathrm{O}$ ministro chefe da Controladoria Geral da União era Jorge Hage. E seu artigo, com o titulo "Sobre Madoff, inveja e soluções" foi publicado na seção "Tendências e Debates" da Folha de S.Paulo em 3 de julho de 2009.

19 Os juristas que a CBJP da CNBB convidara para elaborar o Projeto de Lei eram de competência e experiência inquestionável em questões eleitorais: o Dr. Aristides Junqueira Alvarenga, ex-procurador-geral da República, o Dr. José Gerim Cavalcanti, ex-procurador-regional-eleitoral do Estado Ceará, e o Dr. Dyrceu Aguiar Cintra Jr., ex-juiz eleitoral da Comarca de São Paulo.

20 “Consultor Jurídico” (conjur.com.br).

21 Essa foi uma das decisões positivas para o Projeto tomadas pelo presidente da Câmara dos Deputados.

22 O jurista Dalmo Dallari colocou esses argumentos no artigo "A gramática da Ficha suja", publicado em fevereiro de 2010 (disponível em: <http://www.leieordem. com.br/ficha-limpa-e-a-gramatica.html>).

23 Disponível em: <http://www.cartacapital.com.br/politica/lula-e-a-novela-da-ficha-limpa:.

24 Poema de Carlos Drummond de Andrade. 
RESUMO - O presente texto apresenta a história da Lei da Ficha Limpa, que estabelece a inelegibilidade de candidatos com vida pregressa duvidosa, promulgada em 4 de junho de 2010. Começando pela criação, na Constituinte de 1987-1988, das Iniciativas Populares de Lei como instrumento de participação popular, ele apresenta as dificuldades para apresentar Projetos de Lei dessa forma, os problemas de sua tramitação no Congresso, as potencialidades pedagógicas e de articulação político desse instrumento e as resistências que o Projeto de Lei da Ficha Lima enfrentou, especialmente quanto à questão de Presunção de Inocência. Relata igualmente sua tramitação efetiva, durante oito meses, na Câmara dos Deputados e no Senado, assim como as várias etapas em que a Lei, depois de aprovada e promulgada, foi analisada pelo Tribunal Superior Eleitoral e pelo Supremo Tribunal Federal, que finalmente confirmou sua constitucionalidade em 23 de março de 2011 , depois de mais oito meses de discussão. O texto trata também das ameaças que existem para que tenha seus efeitos diminuídos, analisando decisão recente do STF quanto a um dos seus 21 incisos, bem como a igualmente recente desqualificação de seus autores por um dos ministros dessa Corte. O texto levanta a possibilidade de se ter que defender a Lei da Ficha Limpa ante os interesses representados pelo novo governo, instalado no país em 31 de agosto de 2016.

PALAVRAS-CHAVE: Lei da Ficha Limpa, Inelegibilidade, Vida pregressa de candidatos, Emenda Popular, Iniciativa Popular de Lei

ABSTRACT - This text presents the story of the Clean Record Law, which establishes the ineligibility of candidates with a dubious prior life, enacted on June 4, 2010. Beginning with the creation of the People's Bill Proposal, as defined by the 1987-88 Constituent Assembly, which was to be an instrument of popular participation, this essay examines the difficulties of proposing Bills in this manner, the problems of their proceedings in Congress, the pedagogical and political potential of this instrument, and the resistances that the Clean Record Bill faced, especially on the issue of Presumption of Innocence. It also describes the actual proceedings over an eight-month period in the House of Representatives and in the Senate, as well as the various stages by which the law, after being approved and promulgated, was analyzed by the Superior Electoral Court and by the Supreme Court, which finally confirmed its constitutionality on March 23, 2011, after another eight months of discussion. In addition, this article addresses the threats that exist to diminish the law's effects, analyzing a recent Supreme Court decision on one of its 21 items, as well as the equally recent disqualification of the law's authors by one of the Court's members. Finally, this text raises the possibility of the Clean Record Law having to be defended from the interests represented by the new administration, installed in Brazil on August 31, 2016.

KErWORDs: Clean Record Law, Ineligibility, Prior life of candidates, Popular Amendment, People's Bill Proposal.

Chico Whitaker é membro da Comissão Brasileira Justiça e Paz, um dos fundadores do Movimento de Combate a Corrupção Eleitoral (MCCE). @ - chicowf@uol.com.br

Recebido em 17.10.2016 e aceito em 28.10.2016.

${ }^{\text {I } C o m i s s a ̃ o ~ B r a s i l e i r a ~ J u s t i c ̧ a ~ e ~ P a z, ~ B r a s i ́ l i a, ~ D i s t r i t o ~ F e d e r a l, ~ B r a s i l . ~}$ 